\title{
Does the Conventional Paradigm help to Analyze the Competitiveness of an Industry?
}

\author{
Dr. Federico, G. Topolansky Barbe \\ The Royal Agricultural University, School of Business and Entrepreneurship, \\ GL7 6JS, United Kingdom \\ Dr. Carol, Yongmei Zhang \\ The Royal Agricultural University, School of Business and Entrepreneurship, \\ GL7 6JS, United Kingdom \\ Magdalena, M. Gonzalez Triay \\ University of Gloucestershire, School of Business \\ GL5O 2RH, United Kingdom \\ Mzendah, Clemence \\ The Royal Agricultural University, School of Business and Entrepreneurship, \\ GL7 6JS, United Kingdom

\section{Dr. Federico, G. Topolansky Barbe} \\ (Corresponding Author) \\ The Royal Agricultural University, School of Business and Entrepreneurship, \\ GL7 6JS, United Kingdom
}

Email: federico.topolansky@rau.ac.uk \& agrotopo@hotmail.com

DOI: 10.6007/IJARBSS/v6-i9/2283 URL: http://dx.doi.org/10.6007/IJARBSS/v6-i9/2283

\begin{abstract}
Literature on strategic management has been recently criticised for not being able to explain the success of a number of companies. Within this context, this paper has two main objectives: first, to assess whether one of the most comprehensive strategy models, Porter's diamond (1990) remains valuable to analyse the competitiveness of the Zimbabwean aquaculture industry; and second to produce recommendations to improve the competitiveness of the Zimbabwean tilapia industry. This study uses an intensive research approach, by means of indepth personal interviews with stakeholders from the selected industry. The results of this study indicate that 26 years after its development, Porter's diamond remains a valuable tool to analyse the competitiveness of the Zimbabwean aquaculture industry. Findings have revealed that the main strengths of the Zimbabwean tilapia industry are the availability of natural
\end{abstract}


resources and labour costs. Main weaknesses identified through Porter's framework are: lack of access to capital; lack of access to technology; lack of skilled workers and lack of adequate infrastructure. The findings of this research make a contribution to the existing literature by extending the discussion on the suitability of conventional theory to explain firm competitiveness. To date no other research has been carried out in relation to the development of tilapia aquaculture in Zimbabwe.

Keywords: Conventional paradigm, Zimbabwe, Porter's Diamond, competitiveness, tilapia industry

JEL Code: L1

\subsection{Introduction}

Lack of animal protein in the Zimbabwean diet coupled with government efforts to encourage the development of local food systems make research in this area crucial. The government initiative to develop sustainably produced food became a national issue since Zimbabwe sanctions were imposed in 2004 (Office of Foreign Assets Control 2013).

Zimbabwe has failed to develop a sustainable aquaculture industry despite suitable natural conditions, government institutions, academic institutions and the need for alternative sources of protein. There is no tilapia consumption culture in the country so that the industry requires a well-orchestrated campaign to increase public awareness about the benefits of tilapia consumption. Attributes of tilapia range from nutrition to economic benefits. These may reduce reliance on expensive animal protein sources currently dominated by chicken, pork and beef.

Previous research has revealed the potential of tilapia aquaculture in Zimbabwe (FAO 2014). Most studies on Zimbabwean aquaculture have focused on poverty alleviation. However, there is no commissioned work that has assessed the competitiveness of the Zimbabwe tilapia industry and its potential against competing export countries. This research is meant to shed light on the potential of aquaculture cluster development in Zimbabwe.

Industry competition has been given a lot of attention from both business entrepreneurs and academia. There are several well know theories on international trade and competitiveness. From these theories, Porter's (1990) diamond system was selected as the most suitable framework to analyse the competitiveness of the Zimbabwean tilapia industry.

Porter's (1990) diamond system is a comprehensive model that has the ability to incorporate concepts from traditional trade theory, new strategic trade theory and the role of innovation introduced by Schumpeter (1934). Porter's (1990) framework explains how industries belonging to particular countries can achieve and sustain international competitiveness. His approach recognises the influence that industry drivers and exogenous factors have on firm's level of competitiveness. Moreover, Porter's (1990) approach has the advantage of being developed through the use of case studies. Traditional trade theories lack the depth of understanding of complex relations achieved by Porter thanks to his use of diverse case studies from ten different national contexts. Porter's (1990) 'diamond' provides a useful theoretical framework to study competitiveness of particular industries in a wide range of cultural, spatial, and temporal contexts. 
Existing literature on management and strategy has been strongly criticized. For instance, some scholars argue that traditional models have oversimplified the complexities of management and competition (McGill 1991). Criticizers of conventional theory also claim that the majority of theories were developed using American case studies and collecting primary data from American chief executive officers (CEOs) who oversold success and disguised failure (Rosenzweig 2007). From these interviews - with CEOs - several authors have attempted to develop 'the golden recipe' (Collins 2001; Joyce et al. 2003). Many authors believe that business formulas that were successful in the past are supposed to work again in different times, industries or contexts (Peters \& Waterman 1982). The problem with a strategy recipe is that it has failed to explain the success of many companies such as Ryanair, Apple, Huawei, Aravind, Natura, etc. that have done the opposite of what the conventional paradigm would suggest. These companies have a different mind-set and operate on the basis of unknowns (Gifford 2012). This ability to recognize and be prepared for what is not yet known gives these companies a competitive advantage over conventional companies (Andersen \& Poulfelt 2014). The recipe-based paradigm is being challenged because: is based on uncomfortable assumptions; companies have become vulnerable to outliers, disruptive innovation and unknowns; and the success of black swans. All of these seem to indicate that there is a need for revising the value of the conventional paradigm (Abdersen \& Poulfelt 2014). Within this context, this research will apply and assess the suitability of one of the best well-known theories in the strategy literature. By assessing the suitability of Porter's diamond (1990) to analyse the competitiveness of the Zimbabwean tilapia industry this study makes a contribution to the existing literature by extending the discussion on the suitability of conventional theory to explain firm competitiveness.

\subsection{Aquaculture}

World fish trade has developed rapidly in the last three decades. The increase is in spite of overfished and depleting capture stocks (Keltz \& Bailey 2012). Research conducted by Maldonado and Moreno (2012) indicates that participants behaviours differ under a situation of abundance versus one of scarcity and found that under a situation of scarcity, players overextract a given resource increasing fishing mortalities. In doing so, they obtain less profit, and exacerbate the tragedy of the commons. This research summarises what is currently happening in several countries where fishers continue fishing until all quotas are exhausted.

In spite of being an industry under development, aquaculture is viewed - by many authors - as a solution to the depleting cod crisis in Western Europe and as a main source of seafood with minimal environmental impact (Hilborn 2011; Lucas \& Southgate 2012). FAO (1996) defines aquaculture as the farming of aquatic organisms, including fish, molluscs, crustaceans, and aquatic plants. Farming implies intervention in the rearing process to enhance production, such as regular stocking, feeding and protection from predators. Farming also implies individual or corporate ownership of stock being cultivated. 


\subsection{Tilapia}

Tilapia production is suited to tropical and sub-tropical climate areas. It is a suitable substitute for Atlantic cod due to comparable quality and price. It utilises the following systems: extensive, semi-intensive, intensive, monosex culture, mixed sex culture and polyculture. Nile tilapia (Oreochromis niloticus) is one of the most cultured fish and dominant species used in aquaculture. It has remarkable characteristics such as fast growth, resilience to disease, flavour and texture (Rasheed \& Belal 2010).

Zimbabwe has an underdeveloped aquaculture industry. It is dominated by small scale fishing for personal consumption, limited to rivers and small water bodies. Commercial aquaculture is based on Nile tilapia species with an estimated production of 1,600 tons per annum. Nile tilapia is exotic to Zimbabwe having been introduced from north and central Africa (Suresh \& Bhujel 2012).

The Zimbabwean government has explored and consulted on establishing aquaculture. However, it has failed to develop a coordinated approach to drive sustainable growth in the tilapia industry. Beveridge et al. (2010) argue that the industry is managed by under-resourced cooperatives with no clear entrepreneurship drive to encourage industry growth, competition or innovation.

Zimbabwe has a network of rivers and reservoirs scattered across the country and the government is increasing water reservoirs to minimize runoff. Even though there is a sizeable amount of reservoirs, water bodies are still susceptible to dry and drought seasons (Herald 2012). Research conducted by Basima (2005) indicates that Zimbabwean water quality is suitable for aquaculture production. Zimbabwe used to have the second best road network in Southern Africa. This has been deteriorated due to overutilization and lack of investment. Despite the deteriorating roads networks, most water bodies are accessible by tarred roads with rail line taking up some of the movement of goods on land (Jakes 2016).

Imports hardly affect incumbent fisheries since existing production fails to meet local demand. The shortfall is filled by horse mackerel, a cheaper option than locally produced whole tilapia. Distribution channels are dominated by independent retailers (FAO 2003).

Cod stocks depletion has led to rising imports of tilapia in the EU. There is clear potential for Zimbabwean producers to increase exports in order to meet the demand of this attractive market. Globefish (2010) identifies the UK as another attractive market due to the level of imports and per capita consumption. Most of Tilapia imports come from China.

The tilapia industry has undergone several changes in many countries. Such changes are attributed to technology development, nutrition and genetics improvements, benefits of economies of scale and improved management systems. However, the Zimbabwean industry has failed to generate enough commercial interest and to attract private capital to help its development. The lack of aquaculture policy cohesion in Zimbabwe has resulted in slow commercial development of the industry, limiting aquaculture to a few poorly run cooperatives. The Zimbabwean cooperative system is characterised by the lack of: strategic thinking, access to funding and entrepreneurial skills. In addition, pre to post harvest technology is wholly imported with little local investment in research and development. There is no specific aquaculture training limiting the scope of knowledge for prospective farmers (Lakeharvest 
2010). There is also lack of understanding pertaining to exporting requirements. Broad adoption of a monitoring standard may be the starting point for industry wide acceptance. Monitoring feeding stages would be a challenge in an industry where there are no set standards regarding fish feed formulation resulting in artisanal fisheries resorting to the use of chicken feed for aquaculture (FAO 2003).

\subsection{Competitiveness}

Competitiveness at nation level is arguably best described using Porter's diamond which provides a framework for analysing an industry cluster. The work by Michael Porter takes inspiration from Alfred Marshall who in Principles of economics (1890) spoke about the advantages of industries within localities. The diamond model is a good framework to assess the potential for competitiveness of the Zimbabwean tilapia industry locally and in international markets. Whilst it is accepted that industry conditions are unique from country to country, Porter's model provides a framework for assessing an industry trend and to provide a basis for longitudinal studies to be carried out (Porter 1998).

Porter's diamond (1990) shows a relationship between four sets of factors or attributes which together are supposed to influence or determine the success of an industry. He argues that the more developed and intense the interactions between these four sets of factors, the greater will be the productivity of the firms concerned. Through the national diamond model, Grant (2008), further states that Porter extends our understanding of comparative advantage by examining the dynamics through which specific industries in particular countries develop the capabilities that confer international competitive advantage.

Porter also claims that a nation's most competitive industries are likely to be geographically clustered. Commenting on Porter's diamond, Martin and Sunley (2012) state that the competitive diamond is the driving force making for cluster development. They go on to say that simultaneously the cluster is the spatial manifestation of the competitive diamond.

The "diamond model" has the following four interrelated determinants:

- Factor conditions - the nation's position in factors of production, such as skilled labour or infrastructure, necessary to compete in a given industry;

- Demand conditions - the nature of home demand for the industry's product or service;

- Related and supporting industries - the presence or absence in the nation of supplier industries and related industries that are internationally competitive;

- Firm strategy, structure and rivalry - the conditions in the nation governing, how companies are created, organized, and managed, and the nature of domestic rivalry.

Two other determinants are mentioned, government and chance, though neither is viewed as sufficiently relevant to be formally integrated into the model (Porter 1990).

Despite the value of and considerable agreement on Porter's (1990) contribution to the study of competitiveness, there are criticisms. Chief amongst them:

- The claim that a firm must choose between competing on the basis of differentiation or cost is not always true (Gray 1991).

- Cultural factors and historical antecedents are not given enough attention $\left(\mathrm{O}^{\prime}\right.$ Shaughnessy 1996). 
- Porter's argument of clusters is irrelevant for many industries in different countries (Davies \& Ellis 2000).

- The topic of foreign owned firms is not addressed adequately (Davies 2001).

- Porter's arguments are mainly formulated from case studies of developed nations. All his theory may work in the west, but there is no certainty that would work in developing economies (Hodgetts 1993).

- Porter omits to consider the role of rates of exchange and cash flow in international competition (Gray 1991).

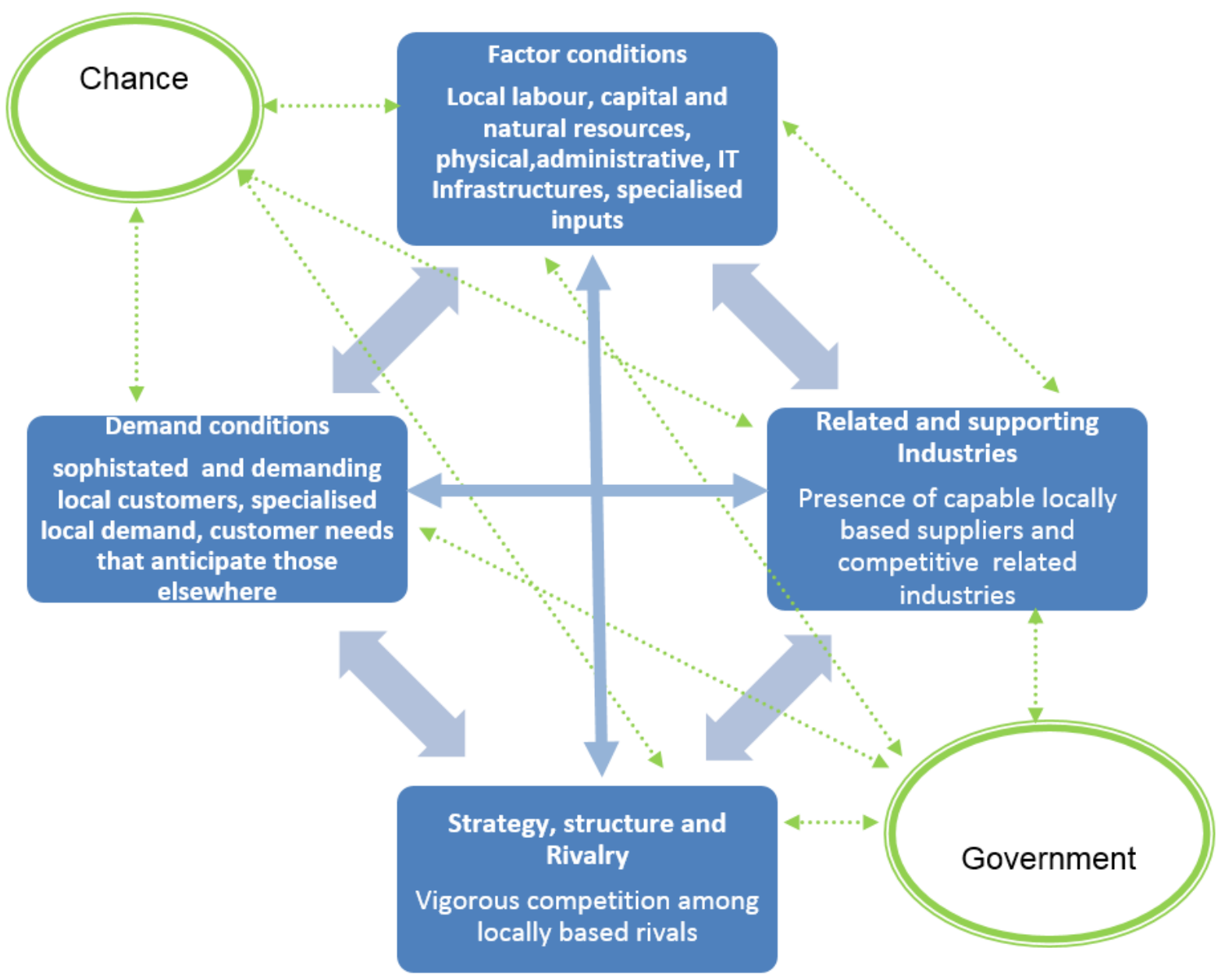

Figure 1: Porter's National Diamond Framework, adapted from Grant (2008)

Porter (1998) defines clusters as "geographic concentrations of interconnected companies, specialised suppliers, service providers, firms in related industries and associated institutions in particular field that compete but also cooperate". The definition points out the core importance of associated and competing firms and industries in the development of competitive advantage by first being locally competitive and also symbiotic.

It is argued that the application of firms' core competencies, resources, and positional advantages can create unique relationships in a value network. These relationships can then be 
used to gain competitive advantage over competitors. Furthermore, when these competencies and resources are considered as a bundle, they become harder to imitate (Martin \& Sunley 2015).

\subsection{Methodology}

An interpretivist, inductive research approach was deemed the most appropriate method to address the objectives of this exploratory research. The application of one of the most comprehensive strategy models has helped to assess the competitiveness of tilapia firms in their industries at home and the potential to compete internationally. This study follows in the established traditions in the field by taking a case study perspective at an industry level. Case studies are a very good way to investigate and test existing theories as well as a source of new hypotheses.

Interviews were selected as the main data collection tool of this research. A semi structured questionnaire informed by the selected theoretical framework was developed to collect primary data. The questionnaire was scrutinized by an expert in aquaculture and an expert in competitiveness. A non-probability sampling method was used to select the sample size. The sample size is not representative of the universe of Zimbabwe tilapia producers. However, the objective of this research is not about representativeness but about exploring the research topic in depth. The criteria used for selecting interviewees was that they should either own a tilapia farm or have been in a senior position for at least two years before the interview.

A total of six face to face in depth interviews were carried out with the owners of two large tilapia producers and four small scale producers in Zimbabwe. The study participants were asked 27 questions in a semi-structured interview format. This interview technique provided an effective and efficient method to gather qualitative information and the opinions of persons who had experience with the issues investigated.

Questions were formulated in English and the interviews were also carried out in English. However, the researchers felt that it was necessary to translate the English questionnaire into Shona for the lesser educated Zimbabwe tilapia producers. In preparation for the interviews emails were sent to the prospective interviewees to make suitable arrangements, followed up by written postal letters. The reason for the communication was to highlight the subject of the research and the purpose of the interviews. All interviews lasted between two and three hours. All interviews were digitally recorded and transcribed and additional 'reflective notes' were developed during the case study. The transcribed interviews were coded and classified using the six step procedure (Radnor 2002). Radnor's technique for analysing and interpreting data follows six key steps, (1) topic ordering, (2) constructing categories, (3) reading for content, (4) completing coded sheets, (5) generating coded transcripts, and (6) analysis to interpretation.

In this study secondary data has played an important role. It has reinforced primary data to address the objectives of this research. To ensure validity and reliability of the research, only official websites and respectable research sources such as Athens, Emerald and Mintel were consulted. 


\subsection{Research Findings}

This section presents the results of the in-depth interviews carried out with key-decision makers from the tilapia industry. Key factors described by Porter's (1990) 'diamond' will be confronted with the collected data to evaluate if they are good predictors of competitiveness for the selected industry.

\section{Factor Conditions}

All interviewees pointed that they do not have access to the optimum resources for tilapia production. For example, water drawing rights and access to equipment seem to be limiting the development of the industry. The lack of domestic suppliers forces most companies to rely on imports of aquaculture equipment.

"... Our hatchery has the capacity to produce our own seed/fry on our hatchery facility and this on its own is not easily replicated. However, we struggle to get access to the right equipment. We have successfully acquired water drawing rights from the Ministry of Water a resource we require..."

"...we do not have specialist equipment, so we do most of our work using simple tools and relying on the local NGO support. Our most priced assets are the ponds that we constructed when we started. We have only 2 ponds measuring $5 * 10$ meters..."

It was mentioned by most respondents that location issues have a direct impact on the performance of the business.

"...we have realized that access to markets is a key factor in our business. The state of roads and transport costs affect the final produce we present to the customer. Unfortunately, we cannot be located near the bigger markets because we need to be close to the water source..."

"...we rely on the efficiency of the logistics system to deliver our produce within a reasonable time scale. I believe that it is important to be nearer competitors as it allows information exchange, however, we are the only commercial producer in the region. Our suppliers are based outside the boarders. For example, our cages come from Norway and some of our feed comes from South Africa leading to higher overhead costs..."

Respondents stated that location also affects access to a qualified labour force. Small producers struggle to generate enough income to pay for qualified employees.

"...it is important to be close to the labour source and along Kariba we have a wealth of experienced pool of employees..."

"...we rely on family labour because we cannot afford to pay and attract aquaculture experienced employees from regions such as Kariba..."

Several respondents raised concerns about the lack of technology developed to cater for the needs and conditions of local production.

"...we have no options but to import technology and equipment for our grower facilities. Our post-harvest facilities are equipped with modern technology that allows us to produce and maintain certification standards. Feed formulation is an area we need to invest in but to date we are reliant on imports..."

Local human resources were identified by four interviewees as one of the factors limiting a further development of the Zimbabwean tilapia industry. According to them it is very difficult to find, in the domestic market, employees with the skills/knowledge to work in tilapia 
aquaculture. Interviewees also stated that there are no specific training courses in the country's learning institutions for tilapia rearing.

"...because there are no tilapia courses in Zimbabwe we offer in-house training to our employees. I think that this situation will remain unchanged due to the lack of promotion of the industry by the government as an alternative source of income and protein..."

"...we could not find the right person for the job on the local market and we hired Adrian (from Mexico) as a manager due to his vast experience working in the aquaculture industry..."

Several respondents indicated that sanctions, inflation, lack of access to capital and currency fluctuations have had a negative impact on the business environment.

"...it is important to have free markets and our business was affected by the public outcry in the UK where we export our produce. The lack of capital still affects the industry and limits growth..."

"...the market is depressed and people can't afford to buy our produce. We have also realised that cheap fish from Namibia entering the country is affecting our produce..."

"...lack of investment capital has limited our growth over the past decade however we recently secured a loan of $\$ 6$ million from the African Development Bank..."

\section{Demand Conditions}

Many people from Sub-Saharan countries suffer from protein deficiency. Theoretically, tilapia could help to address this problem. However, research has shown that local commercial production is largely for export markets and local production is limited in terms of capacity.

"...the local market is not committed to fisheries products and our product would cost more than alternative sources of protein. We also obtain the best price for our produce in foreign markets..."

"...our produce is only meant for the local village people and we cannot produce a lot. Hence we usually sell pond side..."

"...Our produce fetches premium pricing in the EU and UK because of its sustainability and healthy credentials. The market locally is not developed enough to afford tilapia at the cost at which we produce them..."

Five interviewees stated that domestic customers' expectations are the driver and determinant of fisheries products. The Zimbabwean market demands whole fish in small sizes. The UK market is more sophisticated and demands a variety of products.

"...our main customers in the UK and EU are more sophisticated and demand processed tilapia in the form of fillets. Our produce is not frozen as this would diminish the quality of the product before reaching market..."

The results have shown different customer profiles for targeted producers with the small scale producers targeting local villagers in close proximity to their ponds. For the small scale producers sale price is the most important factor. Their target market (villagers) struggle to buy relatively expensive sources of protein such as tilapia. The situation is different for those Zimbabwean producers who export to the UK market. Tilapia customers in the UK are mainly concerned about sustainability and eco-performance. 
"...we are focused on providing the fillets with best possible quality to meet our affluent customer demands..."

\section{Domestic Rivalry}

Six respondents indicated that there is low competition in the markets they operate. This is due to the small number of producers. However, there are some indirect competitors such as importers of horse mackerel.

"...there are not many competitors at the moment. However, horse mackerel from Namibia command a descent market share due to its low prices..."

"...we do not expect industry entrants in the current economic conditions, due to the lack of cheap capital and knowledge however we would benefit from more competitors..."

The results indicate that substitute products strongly affects the performance of tilapia producers. Respondents raised concern of the impact made buy cheaper alternative sources of protein.

"...we are focused on providing best value to our clients. Substitute products contribute more to greenhouse gasses and global warming. Beef, chicken and pork command dominant appeal among Zimbabweans, better than fishery produce..."

"...the directly competing products would be other fish species such as Cod and cheaper meats sourced from abroad..."

\section{Related and Supporting Industries}

The majority of respondents stated that the Tilapia value chain is underdeveloped in Zimbabwe. There are a limited number of suppliers. Therefore, the bargaining power is in the hands of suppliers and this affects input prices.

"...as small producers we are incapable of negotiating with our supplier most of whom exercise their bargaining power. Overcharging is prevalent in this industry with transporters also demanding higher prices..."

\section{Firm Strategy}

Research has shown that owners of large commercial producers in Zimbabwe are well educated and knowledgeable. The strategic direction of the owners is regarded as the driving force of the tilapia production farms.

"...it is very important to have an adequate level of education to be able to face the challenges of running an enterprise. I have used my general agribusiness knowledge to establish the tilapia diversification project. It is also important to hire people with the right skills for the tasks..."

Qualitative data has shown that large producers are competent at developing systems and focusing their campaigns on product attributes. The small scale producers however seem to be focused on output volumes. Lack of knowledge on business systems and market operations are limiting small scale producers to pursue viable long term strategies. 


\section{Government Policy}

Most respondents stated that the Zimbabwean government has not yet developed any policy to support tilapia aquaculture.

"...we collaborate with the University of Zimbabwe research unit based on the lake Kariba monitoring production's impact on the lake. We do not get any form of government support..."

"...we get our help from the local NGO and the government has no input into the tilapia projects..."

\section{Chance Events}

The results indicate that the most significant chance event that has had a significant impact on the progress of tilapia companies in Zimbabwe has been economic sanctions.

\subsection{Discussion}

The analysis of the collected data revealed those factor conditions limiting the development of the tilapia industry. Limitations of capital, infrastructure, specialist skills, energy supply and research institutes constrain industry development.

There are more than 9,000 dams across Zimbabwe, most of which are suitable for tilapia aquaculture. In addition, favourable temperatures and suitable water salinity and pH levels are all conditions for a healthy industry. Whilst closeness to the market is not an issue for exporting businesses, small operators in remote regions struggle to access markets with fresh produce other than village markets. The roads which are not in the best conditions would not be able to support a growing industry.

The availability of local human resources is a factor condition that contributes to the success of firms within the selected industry. Universities, agriculture colleges and technical colleges around the country are solely responsible for producing skilled employees. However, small scale farmers are not able to access a skilled labour pool which is mainly centred in urban areas and demand salaries they cannot afford. Experienced employees are based in regions that already have other forms of fisheries such as the Lake Kariba.

The results of this research show that respondents consider the Zimbabwean population to have a poor understanding of tilapia and fisheries products. Porter (1998) argues that a nation's companies in an industry gain competitive advantage where the local customers or domestic buyers are the world's most sophisticated and demanding. The local tilapia market is anything but sophisticated. Moreover, the majority of the population prefers traditional animal protein sources such as beef and chicken. This lack of active interest in tilapia products is a hindrance to the development of the industry as there is no driver to trigger innovation and investment or to produce a variety of competing products. This is not surprising as tilapia aquaculture production was initially set up to satisfy the export market.

Competitiveness in Zimbabwe is affected by the un-availability of much better functioning support industries. Moreover, supporting industries most of which are monopolies drive the cost of production up. Due to the dependence on imports the domestic industry is susceptible to international currencies fluctuations thereby distorting the value of output products. 
There is lack of competition within the Zimbabwe tilapia industry. There is though indirect competition from traditional sources of protein. Qualitative data suggests that there are no clusters in the tilapia industry and that most firms do not have a clear long term strategy. More importantly, there is no investment in research and development.

Porter argues that a good government policy toward a nation's industry should: stimulate dynamism and upgrading, and create the right environment to spur firms to upgrade competitive advantage. Results of this research suggest that the Zimbabwe government has not helped the development of the tilapia industry.

\subsection{Porter's adapted diamond model: Zimbabwean tilapia industry}

The foregoing analysis identified those factors that are relevant for the development of the Zimbabwean tilapia industry.

The main factor conditions impacting the Zimbabwean tilapia industry are lack of capital, lack of investment and access to skilled workers. Availability of imported fish protein, such as horse mackerel, has resulted in depressed prices for fisheries in Zimbabwe. For this reason, price on its own is a major factor that affects industry rivalry. Therefore, the model is adapted to put more emphasis on rivalry including competition from substitute products.

The aquaculture Zimbabwean structure is heavily influenced by the cooperative and NGO models which are not efficient drivers of commercial excellence and efficiency. Therefore, it was important to consider this as a separate factor.

Domestic demand conditions were not a large contributor of success in the targeted industry as Porter's diamond would have predicted. For the Zimbabwean tilapia industry, foreign demand might play a major role for the success of this industry. Porter's model would not be applicable in its current form. Therefore, the change of focus to export customers reflects the reality of this industry.

The qualitative analysis did support the importance that Porter's 'diamond' gives to the role of government policy. The government has had a negative impact on businesses operating in the Zimbabwean tilapia industry. The government could help the development of this industry by providing extension services, training and subsidies. 




Figure 2: 1Porters' diamond on Zimbabwean tilapia Industry

The above model takes into account those factors and pressures that seem to have shaped the development of firms in this study.

The researchers' view is that Porter's model provides a useful framework to analyse the competitiveness of firms in different industries but the components need to be looked at in detail because the reality of each industry is unique. A few scholars have criticized Porter's model for being too broad and therefore, including everything that might contribute to develop competitiveness, thus identifying nothing as particularly relevant. For this study, the holistic approach of Porter's model has proved to be a valuable framework to unveil reasons for competitiveness. The complexities of understanding competitiveness in an industry require a model that considers external as well as internal factors of competitiveness, and Porter's diamond embraces both of them.

\subsection{Recommendations}

This section elaborates recommendations derived from the primary and secondary collected data that would help the development of the Zimbabwean tilapia industry. 
The government may be required to take a lead role in developing consumer awareness of the benefits of consuming tilapia as a nutritious replacement for traditional sources of protein. The government may also considered to reduce taxes to help start-up firms.

In order to achieve high productivity and to remain competitive when operating in international markets, Zimbabwean firms in general must have access to infrastructure. The government can play a role ensuring that infrastructure constraints are not limiting the progress of domestic firms. There is also a need for domestic firms to adopt international certification standards to aid the development and attractiveness of local produce on the international market.

Traceability has become a paramount factor - for the food industry - affecting consumers' buying behaviour. Implementing traceability in a developing country such as Zimbabwe is not an easy task (Banga et al., 2010). Since Zimbabwe does not have capture fisheries it is important to develop data capture systems that allows for seamless benchmarking in aquaculture against international standards.

Local human resources were identified as one of the factors constraining a major development of interviewed firms. In order to ameliorate this situation, the government should help to develop student exchange programs with stud institutions in countries that have an advanced sector to enable quick knowledge transfer to Zimbabwean students. Collaboration between the private sector and local universities could be initiated to improve research and development in areas that are key for the development of the tilapia sector. It would be sensible to create a government committee with the task to disseminate all information that may help tilapia firms to enhance their productivity and to act as a consultant body.

A good policy must ensure that domestic competitive firms have access to low cost available capital. The lack of access to the nation's capital forced all targeted firms to develop their businesses with their own resources. It is important that the financial markets are carefully regulated. This is the responsibility of the government and careful monitoring of exchange rates should be taken as a matter of urgency since this is one area which has a direct bearing on value of people's investments.

Trade policy is another area where a government can play a role that may help national tilapia firms to achieve competitiveness. So far, the Zimbabwean government has done very little to promote the quality of the tilapia industry in foreign markets.

A carefully thought-out and effectively delivered policy along the topics above mentioned, should have the potential to improve the competitiveness of tilapia firms. However, more research is required to determine its best delivery strategy and implementation cost.

\subsection{Future Research}

Although this study has made significant progress in unveiling those factors that prevent the development of the Zimbabwean tilapia industry, a number of areas still deserve further attention. Further studies should be carried out that outline available credit and forms of funding ranging from government to private sector. The reasons for Zimbabwe's fish-eating habits is a topic that also deserves further exploration. 


\section{References}

Andersen, M. M. \& Poulfelt, F. (2014). Beyond Strategy. The Impact of Next Generation Companies. Taylor \& Francis, New York.

Banga, B, Besbes, B. Balvay, L. Chazo, O.M. Jamaa, A., Rozstalnyy, G., Rovere, A. \& Trivedi, K. R. (2010). Current situation of animal identification and recording systems in developing countries and countries with economies in transition. Retrieved June 27, 2016, from:

https://www.researchgate.net/profile/Cuthbert Banga/publication/265157790 Current situat ion of animal identification and recording systems in developing countries and countries with economies in transition/links/540084e30cf23d9765a3dbdd.pdf

Beveridge, M., Phillips, M., Dugan, P. \& Brummett, R. (2010). Barriers to aquaculture development as a pathway to poverty alleviation and food security: Policy coherence and the roles and responsibilities of development agencies. In: OECD (2010), Advancing the Aquaculture agenda. Proceedings of a workshop, Paris, 15-16 April 2010, 199- 209. Paris, OECD.

Collins, J. (2001). Good to Great: Why Some Companies Make the Leap and Others Don't. Harper Business, New York.

Davies, H., \& Ellis, P. (2000). Porter's Competitive Advantage of Nations: Time for the Final Judgment. Journal of Management Studies, 37(8), 1189-1213.

Davies, T. A. (2001). Enhancing competitiveness in the manufacturing sector: key opportunities provided by inter firm clustering. Competitiveness Review: An International Business Journal, $11(2), 4-15$.

FAO. (2014). Aquaculture future: an analysis. Retrieved June 21, 2016, from:

http://vidatec.org/images/documents/intel14/AquaCulture analysis.pdf

FAO. (1996). Introduction. Retrieved June 24, 2016, from:

http://www.fao.org/DOCREP/003/W4493E/w4493e03.htm

FAO. (2003) Zimbabwe. Retrieved August 12, 2015, from

http://www.fao.org/fi/oldsite/FCP/en/ZWE/body.htm

Giford, J. (2012). Blindsided: How business and society are shaped by our irrational and unpredictable behaviour. Marshall Cavendish Business, London.

Globefish. (2010). FAO GLOBEFISH. Retrieved October 17, 2015, from:

http://www.globefish.org/world-supply-and-demand-of-tilapia.html

Grant, R. (2008). Contemporary strategy analysis. 6th ed. Chichester: Wiley-Blackwell Ltd. Gray, H.P. (1991). International Competitiveness: A Review Article. The International Trade Journal, 5(4), 503-517. 
Herald. (2012). Municipal cops impound two tonnes of fish. Retrieved May 14, 2015, from: http://www.herald.co.zw/index.php?option=com content\&view=article\&id=34867:municipalcops-impound-two-tonnes-of-fish\&catid=37:top-stories\&Itemid=130 Hilborn, R. (2011). Plenary, Seafood Summit. Retrieved May 15, 2016, from: http://www.youtube.com/watch?v=hjiZA4pDiPg

Hodgetts, R.M. (1993). Porter's diamond framework in a Mexican context. Management International Review, 2, 41-54.

Jakes, S. (2016). Zimbabwe has allowed road network to deteriorate - senator. Retrieved June 27, from: http://bulawayo24.com/index-id-News-sc-Local-byo-90339.html

Joyce, W., Nohria, N., \& Roberson, B (2003). What Really Works: The $4+2$ formula for sustained business success. Harper Business, New York.

Keltz, S. \& Bailey, N. (2012). Fish and Shellfish Stocks 2012. Edinburgh: Marine Scotland.

Lakeharvest. (2010). Sustainable Aquaculture of Nile Tilapia / Lake Harvest. Retrieved January 23, 2016, from: http://lakeharvest.com/

Lucas, J. \& Southgate, P. (2012). Aquaculture: Farming Aquatic Animals and Plants (2 ${ }^{\text {nd }}$ ed.). Chichester: Wiley-Blackwell Ltd.

Maldonado, J. \& Moreno, R. (2012). Does scarcity exacerbate the tragedy of the commons? Evidence from fishers' experimental responses. In: Unknown.

Martin, R. \& Sunley, P. (2015). On the notion of regional economic resilience: Conceptualization and explanation. Journal of Economic Geography, 15, 1-42.

McGill, M. E. (1991). American Business and the Quick Fix. Henry Holt \& Co.

Office of Foreign Assets Control. (2013). Zimbabwe Sanctions Program. Retrieved June 21, 2016, from:

https://www.treasury.gov/resource-center/sanctions/Programs/Documents/zimb.pdf

O’ Shaughnessy, N. J. (1996). Michael Porter's Competitive Advantage revisited. Management Decision 34(6): 12 -20.

Peters, T. J. \& Waterman, R. H. (1982). In Search of Excellence: Lessons from America's Best-Run Companies. Harper \& Row, New York.

Porter, M. E. (1998). Competitive Advantage: Creating and Sustaining Superior Performance. New York: The Free Press.

Porter, M.E. (1990). The competitive advantage of nations. London and Basingstoke: The Macmillan Press Ltd.

Radnor, H., (2002). Researching your own professional practice: doing interpretive research. Buckingham: Oxford University Press.

Rasheed, N. \& Belal, I. (2010). Growth Performance of Improved (EXCEL) and a Non-Improved Strains of Oreochromis niloticus Fry in a Recirculating Tank System in the UAE. Journal of Applied Aquaculture, 22 (4), 352-358.

Rosenzweig, P. (2007). The Halo Effect: And the eight other business delusions that deceive managers. Free Press, New York. 
Schumpeter, J.A. (1934). The Theory of Economic Development. Cambridge, Mass.: Harvard University Press.

Suresh, V. \& Bhujel, R. (2012) Tilapias. In: Lucas, J. and Southgate, P. eds. Aquaculture: Farming Aquatic Animals and Plants ( ${ }^{\text {nd }}$ ed.). Chichester: Wiley-Blackwell Ltd, p.338-361. 